\title{
Pinniped disturbance lowers reproductive success of black oystercatcher Haematopus bachmani (Aves)
}

\author{
Kenneth I. Warheit ${ }^{1 *}$, David R. Lindberg ${ }^{2}$ and Robert J. Boekelheide ${ }^{3}$ \\ 1 Center for Coastal Marine Studies, University of California, Santa Cruz, California 95064, USA \\ 2 Museum of Paleontology, University of California, Berkeley, California 94720, USA \\ ${ }^{3}$ Point Reyes Bird Observatory, 4990 Shoreline Highway, Stinson Beach, California 94970, USA
}

\begin{abstract}
Human activities along the Pacific coast of North America have restricted breeding sites of the black oystercatcher Haematopus bachmani to inaccessible stretches of mainland, and offshore islands and islets. These same areas are also used by pinnipeds (exhibiting a similar aversion to human disturbance) for hauling out and breeding. Increasing pinniped numbers are increasing interactions between birds and pinnipeds in these refugia. These interactions result in abandoned nests and crushed eggs and chicks, thus lowering the reproductive success of the black oystercatchers. Complete or partial black oystercatcher colony eradication resulting from pinniped disturbance involves complex interactions between pinniped densities, geographical location, and topographic relief.
\end{abstract}

Disturbance has been recognized as playing an important role in decreasing the reproductive success of birds (Russell, 1973; Olson and Homes, 1982; Pasquier and Jones, 1982; Kirch, 1982). These authors have reported on the direct effects of human disturbance (e.g. habitat destruction) and the resulting population declines and/or extinctions. In coastal habitats, the relation between human disturbance and reproductive failure of colonial seabirds and shorebirds has been particularly well documented (Ainley and Lewis, 1974; Gillett et al., 1975; Kury and Gochfeld, 1975; Robert and Ralph, 1975; Ellison and Clearly, 1978; Tremblay and Ellison, 1979,; Verbeek, 1982). Marine mammals, such as pinnipeds, that use coastal regions for breeding are also extremely sensitive to human disturbance (LeBoeuf and Panken, 1977; LeBoeuf, 1981). As human activity increases in coastal areas, the number of potential breeding sites available to birds and pinnipeds decreases. Because pinniped numbers along the California coast are currently increasing

\footnotetext{
- Present address: Department of Paleontology, University of California, Berkeley, California 94720, USA
}

(LeBoeuf and Bonnell, 1980), any reduction in the number of potential breeding sites increases interspecific contacts (i.e. disturbance) at the remaining sites (usually islands). Although this disturbance involves interactions between marine birds and pinnipeds, and typically takes place without human presence, it is primarily a result of human activities in the nearshore areas.

Black oystercatchers are extremely sensitive to human disturbance. On Southeast Farallon Island, located about $50 \mathrm{~km}$ west of San Francisco, California (USA), black oystercatchers disappeared between 1860 and 1903, during a period of intense human activity (Ainley and Lewis, 1974). A similar situation occurred on Triangle Island (Scott Islands), British Columbia (Canada), from 1910 to 1919 (Carl et al., 1950). Their current distribution in the Channel Islands, California, strongly reflects their aversion to human activities. Among these 8 islands, 3 - Santa Catalina, San Clemente, San Nicolas - have substantially lower densities of black oystercatchers than the remaining 5 islands (Table 1). These 3 islands are relatively more

Table 1. Densities of black oystercatchers in the Channel Islands, California (USA) (bird data from Sowls et al. [1980] perimeter data from US Geological Survey topographic maps)

\begin{tabular}{|c|c|c|}
\hline Island & $\frac{\text { No. breeding birds }}{\text { Rocky intertidal }(\mathrm{km})}$ & Status \\
\hline San Miguel & 2.72 & National Park \\
\hline Santa Barbara & 1.33 & National Park \\
\hline Santa Cruz & 0.99 & Reserve \\
\hline Santa Rosa & 0.88 & Private \\
\hline Anacapa & 0.69 & National Park \\
\hline San Nicolas & 0.08 & US Naval Facility \\
\hline San Clemente & 0.05 & US Naval Facility \\
\hline Santa Catalina & 0.00 & Residential \\
\hline
\end{tabular}


disturbed than any of the others in the group. Santa Catalina is a residential island and a popular vacation spot. Both San Clemente and San Nicolas are US Naval facilities with year-round human habitation and military activities. In addition to direct human disturbance, feral cats have been introduced to these 3 islands (Laughrin, 1980). The remaining 5 islands - Anacapa, Santa Rosa, Santa Cruz, San Miguel, Santa Barbara with their higher black oystercatcher densities, are either National Parks or privately-owned with minimum human disturbance.

Most reproductive failures of black oystercatchers result from predation (Drent et al., 1964; Hartwick, 1974). However, because black oystercatchers are persistent brooders and incubate and/or guard their eggs $98 \%$ of the daylight hours (Helbing, 1977), predation must occur within the short period of time when both adults are simultaneously away from the nest. For breeding pairs in northern California, Helbing (1977) calculated that this occurs on an average of $22 \mathrm{~min} \mathrm{~d}^{-1}$. Black oystercatchers leave their nests unattended during intraspecific territorial disputes and following disturbances near the nest sites. Predation can only occur during these times, and therefore is a result of these events; an increase in disturbance will increase the probability of reproductive failure.

Studies by Drent et al. (1964) and Legg (1954) have clearly demonstrated the adverse effect of human disturbance upon the reproductive success of black oystercatchers. On Mandarte Island, British Columbia, Drent et al. (1964) have attributed the 'unreasonably low' hatching success to human disturbance and subsequent crow predation. Increased egg and chick predation following human disturbance has also been documented in cormorants, herons, willets (Catoptrophorus semipalmatus), guillemots, and gulls (Gillett et al., 1975; Kury and Gochfeld, 1975; Robert and Ralph, 1975; Ellison and Clearly, 1978; Tremblay and Ellison, 1979; Cairns, 1980; Howe, 1982; Hunt, 1972; Verbeek, 1982).

Black oystercatcher reproductive success at Año Nuevo Island, California, in 1982 was extremely poor. In total, only 6 of the 20 eggs laid survived predation by western gulls Larus occidentalis and hatched. Three of the chicks disappeared, presumably due to predation, and 2 were crushed by northern elephant seals Mirounga angusterostris. Only 1 chick was successfully fledged. This latter case of mortality, an interaction with a gregarious pinniped, is not a unique event, but a previously unrecognized and apparently increasing source of egg and chick mortality for these shorebirds.

At Año Nuevo Island gregarious pinnipeds depress black oystercatcher reproductive success in at least 2 ways. Similar to human disturbance, pinniped breed- ing and/or hauling out activities can intimidate the birds and effectively prevent nesting, incubation, or brooding. For example, 2 pairs of black oystercatchers defended territories encompassing dense northern sea lion Eumatopius jubata breeding areas. Both pairs showed signs of nest commencement and 1 pair was observed copulating. However, both pairs failed to establish a suitable nest site and no eggs were laid. Periodic sea lion movements and persistent harassment by the sea lions appeared responsible for this failure. Pinniped disturbance during incubation or brooding can increase the eggs' and/or chicks' vulnerability to predation by forcing the adult birds to leave the nest site; this was observed on several occassions when flooding tides forced California sea lions Zalophus californianus into higher and denser concentrations where oystercatcher nests occurred. A more direct form of pinniped disturbance is the actual crushing of eggs and chicks, such as the 2 chicks crushed by Mirounga at Ano Nuevo Island in 1982.

Deleterious interactions with gregarious marine mammals are not limited to Año Nuevo Island. On Southeast Farallon Island, where 18 pairs of oystercatchers bred in 1982, 3 pairs were displaced by Zalophus californianus from nest sites that they had previously occupied for several years. Two of the 3 pairs failed to renest while the third successfully fledged 1 chick only after moving to an area less disturbed by $Z$. californianus. At least 6 cases of nest and egg destruction by $Z$. californianus have occurred on Southeast Farallon Island since 1980; more nest sites were destroyed and breeding sites vacated in 1982 than in any previous year. Z. californianus numbers at Southeast Farallon Island have increased over the past decade, and they have begun hauling out at previously unused areas of the island. Moreover, they arrived earlier and remained later in 1982 than in any previous year.

Black oystercatcher reproductive success is affected by gregarious pinnipeds. The data from Southeast Farallon Island suggest that an increasing number of black oystercatcher nest sites are becoming vulnerable to disturbance or destruction as pinniped densities increase. However, the vulnerability of black oystercatcher colonies to complete or partial eradication by pinnipeds is not dependent solely on increasing pinniped densities, but involves complex interactions between (1) pinniped densities, (2) geographical location, and (3) topographic relief.

At Año Nuevo Island, 3 species of gregarious pinnipeds reach their peak densities within the black oystercatcher's nesting period (Fig. 1). At other localities, either to the north or south, these peak periods can be different and thus, the probability and intensity of the interactions either increased or 


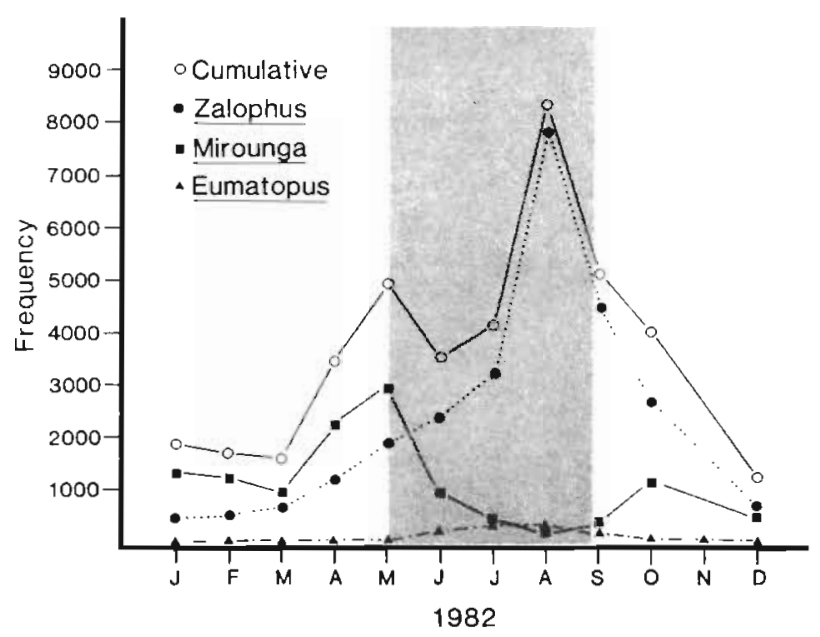

Fig. 1. Censuses of pinnipeds at Año Nuevo Islands, California (USA). Stipled area $=$ black oystercatcher breeding period. Census data: courtesy of R. Condit and B. Le Boeuf

decreased. For example, the vulnerability of black oystercatcher eggs and/or chicks to destruction by pinnipeds should decrease as the oystercatcher breeding season progresses; eggs and newly hatched chicks are more apt to get crushed by pinnipeds than larger chicks capable of avoiding such interactions by running and climbing, or by flight. Therefore, the earlier the pinniped density peaks occur within the black oystercatcher nesting period, the greater the likelihood of an overall decline in the oystercatcher population's reproductive success.

Black oystercatchers may find refuge from pinniped disturbance at localities with varying topography. At Southeast Farallon Island, black oystercatchers disturbed by Zalophus californianus are capable of renesting at sites inaccessible to pinnipeds. However, at a locality such as Año Nuevo Island, where there is no substantial relief, the entire island is accessible to pinnipeds. As a result, black oystercatcher colonies at localities with little relief are more vulnerable to eradication.

As human activity along the California coast increases, competition for space between pinnipeds and black oystercatchers at the remaining undisturbed refugia will also increase. Because of the black oystercatcher's importance in structuring rocky intertidal communities (Castilla, 1981; Frank, 1982; Lindberg et al., in prep.) and their vulnerability to disturbance by humans and pinnipeds, it is important that black oystercatcher, human, and pinniped interactions be monitored at as many sites as possible.

Acknowledgements. We thank C. Chaffee, J. Estes, and B. LeBoeuf for discussion and criticism. R. Condit and B. LeBoeuf provided unpublished data for Fig. 1. We are grateful to the Center for Coastal Marine Studies, University of
California, Santa Cruz, especially S. Davenport, for logistic support. This is Point Reyes Bird Observatory contribution \# 258.

\section{LITERATURE CITED}

Ainley, D. G., Lewis, T. J. (1974). The history of Farallon Island marine bird populations, 1854-1972. Condor 76: $432-446$

Cairns, D. (1980). Nesting density, habitat structure, and human disturbance as factors in Black Guillemot reproduction. Wilson Bull. 92: 352-361

Carl, G. G., Guiget, C. J., Hardy, G. A. (1950). Biology of the Scott Island Group, British Columbia. Rep. Prov. Mus., 1950. Victoria, British Columbia

Castilla, J. C. (1981). Perspectivas de investigación en estructura y dinámica de comunidades intermaveales rocosas de Chile central II. De predadores de Alto Nivel trofico. Medio Ambiente 5: 190-215

Drent, R., van Tets, G. F., Tompa, F., Vermeer, K. (1964). The breeding birds of Mandarte Island, British Columbia. Can. Fld Nat. 78: 208-263

Ellison, L. N., Clearly, L. (1978). Effects of human disturbance on breeding Double-crested Cormorants. Auk 95: 510-517

Frank, P. W. (1982). Effects on winter feeding on limpets by black oystercatchers, Haematopus bachmani. Ecology $63(5)$ : $1352-1362$

Gillett, W. H., Haywood jr., J. L., Stout, J. F. (1975). Effects of human activity on egg and chick mortality in a glaucouswinged gull colony. Condor 77: 492-495

Hartwick, E. B. (1974). Breeding ecology of the black oystercatcher (Haematopus bachmani Audubon). Syesis 7: 83-92

Helbing, G. L. (1977). Maintenance activities of the Black Oystercatcher, Haematopus bachmani Audubon, in northern California. M. Sc. thesis, Humbolt State University, Arcadia, California

Howe, M. A. (1982). Social organization in a nesting population of Eastern Willets (Catoptrophorus semipalmatus). Auk 99: 88-102

Hunt, G. L. (1972). Influence of food distribution and human disturbance on the reproductive success of Herring Gulls. Ecology 53: 1051-1061

Kirch, P. V. (1982). Transported landscapes. Nat. Hist., N. Y 91(12): 32-35

Kury, C. R., Gochfeld, M. (1975). Human interference and gull predation in cormorant colonies. Biol. Conserv. 8: 23-34

Laughrin, L. (1980). Populations and status of the island fox. In: Power, D. M. (ed.) The California islands: Proceedings of a multidisciplinary symposium. Santa Barbara Mus. Nat. Hist., Santa Barbara, California, p. 745-749

LeBoeuf, B. J. (1981). Elephant seals. In: LeBoeuf, B. J. Kaza, S. (ed.) The Natural History of Año Nuevo. Boxwood Press, Pacific Grove, California, p. 327-374

LeBoeuf, B. J., BonnelI, M. L. (1980). Pinnipeds of the California Islands. Abundance and distribution. In: Power, D. M. (ed.) The California islands: Proceedings of a multidisciplinary symposium. Santa Barbara Mus. Nat. Hist., Santa Barbara, California, p. 475-493

LeBoeuf, J. B., Panken, K. J. (1977). Elephant seals breeding on the mainland in California. Proc. Calif. Acad. Sci. 41: $267-280$

Legg, K. (1954). Nesting and feeding of the black oystercatcher near Monterey, California. Condor 56: 359-360

Olson, S. L., Homes, H. F. (1982). Fossil birds from the Hawaitan Islands: evidence for wholesale extinction by 
man before western contact. Science, N. Y. 217 (4560): $633-635$

Pasquier, R. Jones, C. (1982). The lost and lonely birds of Mauritius. Nat. Hist. 91(3): 38-43

Robert, H. C., Ralph, C. J. (1975). Effects of human disturbance on the breeding success of gulls. Condor 77: 495-499

Russell, S. M. (Chairman) (1973). Bird conservation in middle America. Report of the A. O. U. Conservation Committee, 1972-1973. Auk 90; 877-887

Sowls, H. L., DeGange, A. R., Nelson, J. W., Lester, G. S.
(1980). Catalog of California sea bird colonies. U. S. Dept. Interior, Fish \& Wildlife Serv. Biol. Serv. Prog. FWS/OBS $37 / 80$

Tremblay, J., Ellison, L. N. (1979). Effects of human disturbance on the breeding black-crowned night herons. Auk 96: 364-369

Verbeek, N. A. M. (1982). Egg predation by northwest crows: its association with human and bald eagle activity. Auk 99: $347-352$

Accepted for printing on January 21, 1984 